\title{
Economic analysis of rotavirus-associated diarrhea in the metropolitan Toronto and Peel regions of Ontario
}

\author{
P Jacobs DPhil ${ }^{1}$, LG Shane PharmD ${ }^{2}$, K Fassbender PhD ${ }^{1}$, EL Wang MD CM³ \\ R Moineddin $\mathrm{PhD}^{4}$, EL Ford-Jones MD FRCP 5
}

P Jacobs, LG Shane, K Fassbender, EL Wang, R Moineddin, EL Ford-Jones. Economic analysis of rotavirus-associated diarrhea in the metropolitan Toronto and Peel regions of Ontario. Can J Infect Dis 2002;13(3):167-174.

OBJECTIVE: To measure the economic cost of rotavirusassociated diarrhea for a selected group of families, in a nonexperimental setting, and to estimate the factors that influence these costs.

DESIGN: Use and other socioeconomic data from a family survey (the Pediatric Rotavirus Epidemiology Study for Immunization) of children who tested positive for rotavirus were collected for the metropolitan Toronto and Peel regions of Ontario during the rotavirus season of 1997-1998. Service costs were estimated from provider data. A statistical regression analysis was used to explain the variances of provincial health care costs, prescription drug costs and indirect (work-loss) costs.

SETTING: Data were collected in hospitals, emergency rooms, paediatric practices, primary care clinics and licensed daycare centres. Hospital coverage was wide, but community coverage was not. PATIENTS AND OTHER PARTICIPANTS: Children with diarrhea were tested for rotavirus. Those who tested positive and whose parents consented for their children to participate were included in the study.

INTERVENTIONS: None

MAIN OUTCOME MEASURES: The main outcomes were provincial health care costs, drug costs, nonmedical costs and the number of days of work missed by parents per child, as well as factors that determine these costs.

RESULTS: Children in the most severe category incurred costs of $\$ 2,663 /$ person, and those in the least severe categories incurred costs of approximately $\$ 350 /$ person. The most important determinant to explain provincial health care costs was the number of health problems that the child had before having rotavirus. Costs due to work loss of parents were considerable for children in all severity groups and were influenced by family working conditions. CONCLUSIONS: When considering the economic implications of rotavirus, prior health status should be considered and indirect costs should be recognized for their importance.

Key words: Cost; Cost analysis; Rotavirus

Résumé à la page suivante

\footnotetext{
${ }^{1}$ Department of Public Health Sciences, University of Alberta and Institute of Health Economics, Edmonton, Alberta; ${ }^{2}$ GlaxoSmithKline Canada, Toronto, Ontario (formerly with Wyeth-Ayerst Canada, Inc); ${ }^{3}$ Aventis Canada, Toronto, Ontario; ${ }^{4}$ Department of Biostatistics, University of Toronto, Ontario; ${ }^{5}$ Division of Infectious Diseases, The Hospital for Sick Children and University of Toronto, Toronto, Ontario Correspondence and reprints: Dr Philip Jacobs, Institute of Health Economics, 1200-10405 Jasper Avenue, Edmonton, Alberta T5J 3N4.

Telephone 780-448-4881, fax 780-448-0018, e-mail Philip.Jacobs@Ualberta.Ca
}

Received for publication November 17, 2000. Accepted April 25, 2001 


\section{Analyse économique de la diarrhée à rotavirus dans les régions métropolitaines de Toronto et de Peel, en Ontario}

OBJECTIFS : Évaluer les coûts de la diarrhée à rotavirus dans un groupe sélectionné de familles, en milieu non expérimental, et étudier les facteurs qui influent sur ces coûts.

PLAN D’ÉTUDE : Nous avons utilisé, entre autres, les données socioéconomiques recueillies dans le cadre d'une enquête menée dans les régions métropolitaines de Toronto et de Peel, en Ontario, au cours de la saison 1997-1998, auprès de familles ayant des enfants dont les résultats d'examens ont confirmé la présence de rotavirus (Pediatric Rotavirus Epidemiology Study for Immunization). Les coûts des services ont été évalués à partir de données provenant de fournisseurs. Nous avons procédé à une analyse de régression statistique pour expliquer les variances de coûts liés à la prestation de soins, à l'achat de médicaments et à des facteurs indirects (absentéisme).

MILIEU : Les données ont été recueillies dans des hôpitaux, des salles d'urgence, des cabinets de pédiatrie, des cliniques de soins primaires et des garderies autorisées. Le champ d'observation dans les hôpitaux était étendu, mais pas celui dans la collectivité.
PATIENTS ET AUTRES PARTICIPANTS : Les enfants souffrant de diarrhée ont subi des tests pour savoir s'ils étaient porteurs de rotavirus. Ceux pour lesquels les résultats ont été positifs et dont les parents ont accepté de participer à l'étude ont été sélectionnés.

INTERVENTION : Aucune

MESURES DES PRINCIPAUX PARAMÈTRES : Les principaux paramètres étaient les coûts liés aux soins de santé, aux médicaments, aux services ou aux produits non médicaux et le nombre de jours de travail manqués par les parents, par enfant, ainsi que les facteurs déterminants de ces coûts.

RÉSULTATS : Les enfants les plus gravement malades ont occasionné des coûts de 2663 \$/personne et les enfants les moins malades, de 350 \$/personne. Le facteur déterminant le plus important pour expliquer les coûts soins de santé était le nombre de problèmes de santé que les enfants présentaient avant de devenir porteurs du rotavirus. Quant aux coûts liés à l'absentéisme des parents, ils atteignaient des sommes considérables, peu importe le degré de gravité, et ces coûts variaient en fonction des conditions familiales de travail.

CONCLUSION : Les deux points importants à considérer dans le fardeau économique des maladies à rotavirus sont l'état de santé des enfants avant d'en devenir porteurs et les coûts indirects.
$\mathrm{R}_{\mathrm{t} \text { ond }}^{\mathrm{o}}$ otavirus is the major virus that causes severe gastroenteritis in young children (1). Gastroenteritis, a common and seasonal disease, includes symptoms of diarrhea and vomiting. If body fluid loss is significant, the child can experience a loss of electrolytes, leading to dehydration. Children with severe cases of gastroenteritis are usually hospitalized so that intravenous or oral rehydration can be provided. There is a significant disease burden as a result of gastroenteritis. In the United States, it is estimated that 30,000 hospitalizations occurred due to rotavirus in 1995 . Twenty to forty deaths occur annually due to rotavirus (2).

The economic burden of diarrhea with a rotavirus etiology in children was addressed in two studies. Using experimental data from large, randomized clinical trials, Griffiths et al (3) in the United States and Tukala et al (4) in Finland identified high hospitalization costs and productivity losses due to rotavirus-related gastroenteritis in children. At present, there are no comparable estimates of rotavirus events in Canada. Very little is known about the factors that influence the cost of rotavirus-associated diarrhea.

Because rotavirus-associated diarrhea is usually more severe than diarrhea with other etiologies, cost data on this topic, specifically, must be obtained when considering the role of a future rotavirus vaccine program. Furthermore, although researchers have presented descriptive analyses of rotavirus costs, they have not identified predictive factors, such as prior health status, duration of illness and family work conditions, which may explain these costs. Finally, researchers $(3,4)$ have studied the economic burden of rotavirus in experimental contexts, but not under actual practice conditions.

In the 1997-1998 epidemic season, the Pediatric Rotavirus Epidemiology Study for Immunization (PRESI) study group in the Toronto and Peel regions undertook a large-scale hospital and more limited-scale outpatient and community survey of the extent of rotavirus in the metropolitan Toronto and Peel regions of Ontario. An economic survey was conducted for those who tested positive for rotavirus. In the present paper, the results of the economic survey are reported with the objective of measuring the economic (societal) costs of rotavirus-induced diarrhea under actual practice conditions, and the factors that influence these costs are also reported.

\section{DATA AND METHODS}

From November 1997 through June 1998, 49 sites in the Toronto and Peel metropolitan area were surveyed $(5,6)$. These included 18 hospitals, eight emergency care rooms, 19 daycare centres and four paediatric practices. Other than the hospitals (which were fully surveyed), the nonhospital sites formed a nonrepresentative sample. All children at the 49 sites who had symptoms of diarrhea were identified $(n=2524)$. Stool samples were collected and tested with a commercial IDEIA rotavirus test (Dako Diagnostics, Canada) and were confirmed by electron microscopy. If the children tested positive for rotavirus, their physicians and parents were asked to participate in the present survey, and, if they agreed, a telephone survey (socioeconomic questionnaire) was conducted at the time of diagnosis and at onemonth follow-up.

In the survey, data on utilization were collected for a number of types of services and categories of costs. A standard cost was developed for each service (Appendix I). The services and costs were aggregated into five categories: provincial health services (inpatient and outpatient hospital and physician services); prescription drugs (including rehydration fluids); other supplies (including nonprescription drugs, diapers and clothes); transport costs (including taxis, parking, public transport and a mileage allowance for those taking their own cars); and time lost from work. Per 
person costs were derived for each of the categories reported. The sample was classified into four groups that represented levels of severity, as approximated by health care utilization (7). These were: child was admitted to hospital; child was seen in the emergency room (but was not subsequently hospitalized); child visited a doctor (but not in emergency room or hospital); and child was not seen in any of the above formal health care settings. For each of the four categories, data were gathered on the number of persons who incurred costs as well as on descriptive statistics for those costs.

Regression equations were developed to explain the determinants of three groups of services - provincial health care costs, those drug costs that were eligible for private health insurance in at least some plans (ie, excluding overthe-counter medications), and the indirect costs of the loss of work. Regression equations were not developed for the other categories (transport and nondrug supplies) because of the lack of appropriate explanatory indicators in the survey for these variables.

In the regression equation for provincial health care costs, the following variables, commonly used in the utilization literature, were included: the age of the child, the child's previous health status (measured by the number of previously identified medical problems), the duration of symptoms, and binary variables that summarized membership in one of three severity groups - severe (hospitalization), moderate (emergency room treatment) and mild rotavirus (physicians' offices or no formal treatment). The severity indicator of the two lowest severity groups was collapsed into a single group because of the small number of children in those groups. With regard to the binary variables, the mild group was omitted for the purpose of the regression equations, and the other two groups were, therefore, analyzed with reference to the mild group.

Regression models were developed for prescription drug utilization, but because prescription drug costs represent a small and less important aspect of costs associated with rotavirus, these results are summarized only briefly.

Days off work due to child illness, multiplied by the average daily Ontario wage, was the measure of lost income. Not all families who had at least one working member lost income. Using data from those families with at least one working parent, a binary logistic equation was developed. The dependent variable was a binary variable indicating whether the family had any reported lost income. Independent variables were: age of child, duration of illness, parental living arrangements (living alone $=0$, living with partner=1), numerical education level of parent, income class (categorized income level) of parent, number of working parents, and how the child was cared for when the parent worked (in-home=0, out-of-home=1). For those working families who did lose income, a linear regression equation was developed to explain the amount of income lost (time lost from work multiplied by the average daily Ontario wage). This variable was a descriptor of lost time, because the value of a lost day of work is assumed to be the
TABLE 1 Characteristics of individual rotavirus patients in
sample of study participants

\begin{tabular}{lc}
\hline Characteristic & Occurrence (\%) \\
\hline Number of completed interviews & 421 \\
Number of interviews with missing data & 6 \\
Number of parents refusing interviews & 37 \\
or unable to respond & \\
Total number contacted & 464 \\
Age of patient & \\
Younger than six months & $28(6.7)$ \\
6-23 months & $261(62.0)$ \\
$24-35$ months & $61(14.5)$ \\
36 months or older & $71(16.9)$ \\
Mean value (Standard deviation) & $23.21(20.43)$ months \\
Previous health status & $328(77.9)$ \\
No identified medical problems & $75(17.8)$ \\
Number with one medical problem & $12(2.9)$ \\
Number with two medical problems & $6(1.4)$ \\
Missing &
\end{tabular}

same for everyone, and it therefore abstracts from occupational differences. The independent variables in this equation were the same as those that were used in the logistic regression.

\section{RESULTS}

Description of the sample

A total of 1638 children were admitted to hospital. Of those, $1001(61 \%)$ were tested, and $372(37 \%)$ of those tested positive for rotavirus. In outpatient settings, 886 children had diarrhea, of whom 397 (45\%) were tested. Of these, 92 children $(23 \%)$ tested positive for rotavirus. In total, 464 parents of children with rotavirus were contacted and were asked to respond to the socioeconomic questionnaire. Thirty-seven were excluded because of a lack of consent, inadequate communication in English or the authors' inability to contact them by telephone. Four-hundred twentyseven agreed to reply to the questionnaire. Six of those had missing data, and, therefore, 421 responses were usable.

Age distribution and other characteristics of the children and their families are shown in Table 1. The majority 
TABLE 2

Basic cost data by level of care (severity group) from an economic analysis of rotavirus-associated diarrhea in the metropolitan Toronto and Peel regions of Ontario

\begin{tabular}{|c|c|c|c|c|}
\hline Cost category & $\begin{array}{l}\text { Number for whom } \\
\text { costs were more than } 0 \\
\text { (\% of total) }\end{array}$ & $\begin{array}{l}\text { Mean value } \\
\text { of costs (\$) }\end{array}$ & $\begin{array}{c}\text { Standard } \\
\text { deviation (\$) }\end{array}$ & $\begin{array}{l}\text { Median } \\
\text { (\$) }\end{array}$ \\
\hline \multicolumn{5}{|l|}{ Child was hospitalized $(n=343)$} \\
\hline Direct costs & $343(100.0)$ & 2,261 & 1,525 & 1,824 \\
\hline Provincial health care costs & $343(100.0)$ & 2,125 & 1,492 & 1,704 \\
\hline Inpatient hospital care & $343(100.0)$ & 1,943 & 1,491 & 1,527 \\
\hline Emergency room care & $325(94.8)$ & 173 & 72 & 129 \\
\hline Clinic and physician office care & $181(52.8)$ & 33 & 17 & 25 \\
\hline Other direct costs (out-of-pocket) & $343(100.0)$ & 136 & 96 & 114 \\
\hline Prescription drugs and rehydration fluids & $218(63.6)$ & 27 & 29 & 20 \\
\hline Other services & $314(91.5)$ & 39 & 31 & 30 \\
\hline Transport & $335(97.7)$ & 85 & 81 & 62 \\
\hline Indirect costs & $254(74.1)$ & 579 & 526 & 516 \\
\hline Total of all categories & $343(100.0)$ & 2,690 & 1,650 & 2,290 \\
\hline \multicolumn{5}{|l|}{$\begin{array}{l}\text { Child was seen in emergency room, but was not } \\
\text { hospitalized }(n=33)\end{array}$} \\
\hline Direct costs & $33(100.0)$ & 320 & 120 & 307 \\
\hline Provincial health care costs & $33(100.0)$ & 214 & 71 & 179 \\
\hline Emergency room care & $33(100.0)$ & 168 & 60 & 129 \\
\hline Clinic and physician office care & $27(81.8)$ & 56 & 31 & 50 \\
\hline Other direct costs (out-of-pocket) & $33(100.0)$ & 106 & 80 & 83 \\
\hline Prescription drugs and rehydration fluids & $28(84.8)$ & 31 & 21 & 29 \\
\hline Other services & $33(100.0)$ & 45 & 60 & 26 \\
\hline Transport & $31(93.9)$ & 37 & 28 & 35 \\
\hline Indirect costs & $24(72.7)$ & 672 & 1,170 & 452 \\
\hline Total of all categories & $33(100.0)$ & 809 & 1,063 & 675 \\
\hline \multicolumn{5}{|l|}{ Child was seen in physician's office $(n=35)$} \\
\hline Direct costs & $35(100.0)$ & 116 & 50 & 116 \\
\hline Provincial health care costs & $35(100.0)$ & 66 & 32 & 50 \\
\hline Clinic and physician office care & $35(100.0)$ & 66 & 32 & 50 \\
\hline Other direct costs (out-of-pocket) & $35(100.0)$ & 50 & 33 & 45 \\
\hline Prescription drugs and rehydration fluids & $17(48.6)$ & 24 & 19 & 21 \\
\hline Other services & $34(97.1)$ & 31 & 21 & 22 \\
\hline Transport & $30(85.7)$ & 9 & 7 & 6 \\
\hline Indirect costs & $26(74.3)$ & 377 & 186 & 258 \\
\hline Total of all categories & $35(100.0)$ & 396 & 240 & 398 \\
\hline \multicolumn{5}{|c|}{ Child was not seen in a formal health care setting $(n=10)$} \\
\hline Direct costs & $10(100.0)$ & 20 & 17 & 18 \\
\hline Other direct costs (out-of-pocket) & $8(80.0)$ & 25 & 16 & 25 \\
\hline Prescription drugs and rehydration fluids & $5(50.0)$ & 8 & 2 & 8 \\
\hline Other services & $7(70.0)$ & 21 & 12 & 17 \\
\hline Transport & $2(20.0)$ & 6 & 7 & 6 \\
\hline Indirect costs & $8(80.0)$ & 387 & 207 & 387 \\
\hline Total of all categories & $9(90.0)$ & 366 & 230 & 387 \\
\hline
\end{tabular}

$n$ Number 
TABLE 3

Results of regression analysis in an economic analysis of rotavirus-associated diarrhea in the metropolitan Toronto and Peel regions of Ontario

\begin{tabular}{|c|c|c|c|}
\hline Dependent variable & $\begin{array}{l}\text { Provinical } \\
\text { health care } \\
\text { costs: } \\
\text { coefficient } \\
\text { (standard error) }\end{array}$ & $\begin{array}{l}\text { Lost income, } \\
\text { no=0 and yes }=1 \text { : } \\
\text { coefficient } \\
\text { (standard error) }\end{array}$ & $\begin{array}{l}\text { Amount of lost } \\
\text { income if losses } \\
\text { are less than } 0 \text { : } \\
\text { coefficient } \\
\text { (standard error) }\end{array}$ \\
\hline Number of observations & 405 & 297 & 248 \\
\hline Constant term & $\begin{array}{l}-229.27 \\
(251.46)\end{array}$ & $\begin{array}{c}0.294 \\
(1.009)\end{array}$ & $\begin{array}{c}227.03 \\
(218.19)\end{array}$ \\
\hline Age of child & $\begin{array}{l}-7.87^{*} \\
(3.12)\end{array}$ & $\begin{array}{c}0.019 \\
(0.012)\end{array}$ & $\begin{array}{l}-0.58 \\
(1.79)\end{array}$ \\
\hline Number of previous illnesses & $\begin{array}{l}494.90 * * \\
(131.34)\end{array}$ & & \\
\hline Duration of illness & $\begin{array}{l}60.82^{\star *} \\
(18.18)\end{array}$ & $\begin{array}{c}0.030 \\
(0.047)\end{array}$ & $\begin{array}{l}23.22 * \\
(10.33)\end{array}$ \\
\hline $\begin{array}{l}\text { Hospitalization or not (hospitalization }=1 \text {, } \\
\text { primary or no formal care }=0 \text { ) }\end{array}$ & $\begin{array}{l}1989.44^{\star *} \\
(230.43)\end{array}$ & & \\
\hline $\begin{array}{l}\text { Emergency room (without hospitalization) } \\
\text { or not (emergency room care }=1 \text {, } \\
\text { primary or no formal care }=0 \text { ) }\end{array}$ & $\begin{array}{c}215.76 \\
(315.55)\end{array}$ & & \\
\hline $\begin{array}{l}\text { Parental living arrangements (alone }=0, \\
\text { with partner }=1 \text { ) }\end{array}$ & & $\begin{array}{l}-0.421 \\
(0.700)\end{array}$ & $\begin{array}{c}103.37 \\
(135.42)\end{array}$ \\
\hline Education level of parent & & $\begin{array}{l}-0.037 \\
(0.147)\end{array}$ & $\begin{array}{l}28.38 \\
(34.70)\end{array}$ \\
\hline Income level of parent & & $\begin{array}{l}-0.020 \\
(0.063)\end{array}$ & $\begin{array}{l}-11.91 \\
(14.65)\end{array}$ \\
\hline Number of working parents & & $\begin{array}{l}1.043^{* *} \\
(0.322)\end{array}$ & $\begin{array}{c}68.12 \\
(53.07)\end{array}$ \\
\hline $\begin{array}{l}\text { Care of child when parent working (in home=0, } \\
\text { out of home=1) }\end{array}$ & & $\begin{array}{l}-0.897^{\star} \\
(0.421)\end{array}$ & $\begin{array}{c}-113.99 \\
(82.27)\end{array}$ \\
\hline $\mathrm{R}^{2}$ & 0.293 & 0.105 & 0.040 \\
\hline
\end{tabular}

Significance levels ${ }^{\star} 0.01-0.05 ;{ }^{*} 0-0.01 ; R^{2}$ measure of goodness of fit

of the children $(62 \%)$ were between the ages of six and 23 months. Seventy-eight per cent of the children had no previous serious medical problems; however, 75 (18\%) had one previous medical problem. The most common medical problems were respiratory ( $42 \%$ of all problems), dermatological $(12 \%$ of all problems) and cardiovascular $(8 \%$ of all problems). Two-thirds of the illnesses lasted from five to nine days, and approximately one quarter lasted fewer than five days. Most $(343,82 \%)$ of the children in the sample were hospitalized (ie, were in the 'severe illness' category).

\section{Measurement of cost per person}

The overall mean cost per family was $\$ 2,301(\mathrm{SD} \pm \$ 1,731)$. The mean value for provincially funded health care services (mainly hospital care, emergency room care and physician services) was $\$ 1,796$ ( $\mathrm{SD} \pm \$ 1,551)$. The remainder of total costs were either indirect costs from work loss (mean value of $\$ 565$ [SD \pm \$579]) or other costs, including nonprescription drugs, other supplies and transport (mean value of \$124 [SD \pm \$95]).

In Table 2, the costs of each service or cost item by severity group are reported. In the case of hospitalized patients, hospital costs were the major expense. In all other categories, indirect costs were the major cost category.

Analysis of provincial costs

The results of the regression equation, in which the dependent variable was provincial cost per person, are reported in Table 3. These results indicate that a previous health problem was statistically significant, increasing average costs by $\$ 495$ for each additional previous condition. Other variables that were statistically significant were age 
TABLE 4

\section{Values of variables in the lost income equations for respondent}

\begin{tabular}{lc}
\hline Variable description & Value (\%) \\
\hline Parental living arrangements & $338(80.3)$ \\
Living with partner & $72(17.7)$ \\
Not living with partner & $11(2.6)$ \\
Missing data & \\
Education of answering parent & $56(13.3)$ \\
Did not complete high school & $119(28.3)$ \\
Completed high school & $236(56.1)$ \\
Attended school beyond high school & $10(2.4)$ \\
Missing data & \\
Income class of household & $65(15.4)$ \\
Less than $\$ 20,000$ & $114(27.1)$ \\
\$20,000-\$49,000 & $113(26.8)$ \\
\$50,000-\$99,999 & $46(10.9)$ \\
More than $\$ 100,000$ & $83(19.7)$ \\
Missing data & \\
Number of working persons in household & $45(10.7)$ \\
Zero & $135(32.1)$ \\
One & $199(47.3)$ \\
Two & $34(8.1)$ \\
More than two & $8(1.9)$ \\
Missing data & \\
Out of home & \\
\hline
\end{tabular}

(each month of age was associated with a decrease in cost of $\$ 8)$, duration of illness (\$61 per additional day of illness), and hospitalization ( $\$ 1,989$ more than low severity costs if the patient was hospitalized). Being seen in the emergency room did not significantly affect provincial costs compared with the low severity group.

\section{Analysis of drug costs}

Significant factors in the equation that determine whether persons used prescription drugs were age (negatively related), number of previous illnesses (positively related) and duration of illness (positively related). For those who obtained some prescription drugs $(n=260)$, age of child (negatively related) and duration of illness (positively related) were related significantly to drug expenses.

\section{Analysis of indirect costs}

Most (80\%) of the parents lived with a partner, and 56\% attended school beyond high school (Table 4). Only 15\% of households earned less that $\$ 20,000$ per year; there were two working persons in $47 \%$ of the households. In $58 \%$ of the sample, the parent at home normally cared for the children.
The regression equation that explained income loss was run on data from 297 families - those with at least one reported working member (hence, who could potentially lose income). The variables that were related significantly to whether income was lost were the number of working parents and where the child was cared for while the parent was working. Families with two working members were almost two times more likely to report an income loss than families with one working parent. Parents were $60 \%$ less likely to report an income loss when the children were normally cared for in the home.

A total of 248 family members who were working actually reported having taken some days off work. The results of the regression equation explaining lost income (Table 3) indicate that only the duration of illness was related significantly to the amount of income loss (an increase of illness by one day results in an increase lost income of $\$ 23$ ).

\section{DISCUSSION AND CONCLUSIONS}

For the families in the sample, hospitalization, emergency room, transport and indirect costs were the most frequently incurred costs. Societal costs for children treated in hospital were $\$ 2,690$ per child, and costs for cases treated in the emergency room (but not hospitalized) were $\$ 809$. When considering the indirect costs of work loss, rotavirus costs were considerable even for those families where care was sought only in a doctor's office or not at all. Most of the costs for families with children in the low severity category were due to work loss. The equation explaining provincial health expenditures performed quite well overall. The work-loss equation indicated that circumstances of the family were key contributors toward explaining the probability of work loss. Illness severity was the key determinant of how much time was lost from work.

A key finding from the regression analysis of provincial health care costs was that a child's previous health status was a statistically significant indicator of health care utilization and was of a considerable magnitude. An analysis of subgroups revealed that the previous health status variable was associated positively with hospitalization, and for those who were hospitalized, this variable was associated with higher provincial costs. For those who were not hospitalized, previous health status was not a significant determinant of provincial costs.

It should be pointed out that the sample in the PRESI study was not representative of the entire population with rotavirus. While PRESI achieved wide coverage in the hospital survey, it did not achieve anywhere near complete coverage from the other sites. It is likely that the hospital sample captured more severe cases than the entire group of hospitalized rotavirus cases - not all hospitalized cases were tested for rotavirus, and those who were tested had longer stays (5) and were likely to be more severely ill. The nonhospital sample also contained a considerable number of nonsampled cases. There is no evidence to assess whether nontested cases were of lower severity than those who were tested (6). The sensitivity 
and specificity of the test are other potential reasons why less serious cases may be missed, and hence, positively tested cases might be more severe than true positive cases. However, the sensitivity of the IDEIA test was $100 \%$ and specificity was $99.2 \%$ compared with electron microscopy; therefore, this additional possibility is unlikely to be a factor that results in higher severity cases being included (8).

It should also be emphasized that the PRESI results were based on self-reported data, and its accuracy needs to be verified. We were able to verify that the events of hospital- ization were reported accurately; however, the length of stay was self-reported at 3.1 days and was reported by the study nurses at 2.4 days. Therefore, total hospital costs, which were based on days of care, could be over-estimated by $29 \%$. Other costs were based on events, and there was no method to validate those costs.

ACKNOWLEDGEMENT: This research was supported by an unrestricted grant from Wyeth-Ayerst Canada.

\begin{tabular}{|c|c|c|}
\hline \multicolumn{3}{|c|}{$\begin{array}{l}\text { APPENDIX I } \\
\text { Sources of cost data }\end{array}$} \\
\hline Resource item & Measure of output & Method used to measure cost \\
\hline Inpatient hospitalization (ward) & $\begin{array}{l}\text { Days of care, including } \\
\text { attending physician's service }\end{array}$ & $\begin{array}{l}\text { Hospital component: Per diem Resource Intensive Weight for Case } \\
\text { Mix Group } 294 \text { (Gastroenteritis, under age 70) of } 0.2023 \text { (9) } \\
\text { applied to cost per weighted case for each study hospital (10). } \\
\text { Physician components based on Ontario Schedule of Benefits } \\
\text { (11), admission assessment (code C264, \$32.55) and daily visit } \\
\text { (code C262, 7.10) }\end{array}$ \\
\hline $\begin{array}{l}\text { Inpatient hospitalization - } \\
\text { paediatric intensive care }\end{array}$ & Days of care & $\begin{array}{l}\text { Estimated paediatric intensive care unit cost per day } \\
\text { from study hospital }(\$ 1,200)\end{array}$ \\
\hline Emergency room visit & $\begin{array}{l}\text { Visit, including fee for } \\
\text { emergency room attending } \\
\text { physician }\end{array}$ & $\begin{array}{l}\text { Mean value of emergency room cost and intravenous fluids, } \\
\text { including allocated costs from diagnostic centres, for three study } \\
\text { hospitals ( } \$ 91 \text { per visit). Ontario physician fees for emergency } \\
\text { room partial consultation }(\$ 38)(11, \text { code } A 414)\end{array}$ \\
\hline Physician office visits & Visits & $\begin{array}{l}\text { Fee per visit for paediatric consultation (Ontario Schedule of } \\
\text { Benefits, code A263, \$49.85) and general practitioner (11, code } \\
\text { A007, \$24.80) }\end{array}$ \\
\hline $\begin{array}{l}\text { Prescription medications - } \\
\text { antibiotics and other }\end{array}$ & $\begin{array}{l}\text { Prescription, by number of } \\
\text { days drug taken at home }\end{array}$ & $\begin{array}{l}\text { Antibiotics: a standard cost based on the Ontario Drug Benefits plan } \\
\text { (12) for amoxycillin ( } 125 \mathrm{mg} \text {, three times daily) ( } \$ 2.10 \text { per seven } \\
\text { days) plus dispensing fee ( } \$ 11 \text { flat rate). Drugs other than antibi- } \\
\text { otics: actual cost as reported in questionnaire }\end{array}$ \\
\hline $\begin{array}{l}\text { Oral rehydration fluids, over-the- } \\
\text { counter medications, other } \\
\text { supplies }\end{array}$ & & Cost as self-reported \\
\hline $\begin{array}{l}\text { Other services, such as diapers, } \\
\text { toys, clothes, supplies, diaper } \\
\text { creams, baby wipes, vaseline, } \\
\text { laundry }\end{array}$ & & Costs as self-reported \\
\hline Transportation & $\begin{array}{l}\text { Out-of-pocket expenses } \\
\text { (public transport, taxi, } \\
\text { parking, accommodation) and } \\
\text { kilometres travelled for medical } \\
\text { care and supplies }\end{array}$ & Self-reported outlays and travel at $23 \varnothing / \mathrm{km}$ \\
\hline Lost work & Days & Average daily earnings in Ontario, July 1998 (\$129 per day) (13) \\
\hline
\end{tabular}




\section{REFERENCES}

1. Ruuska T, Vesikari T. Rotavirus disease in Finnish children: Use of numerical scores for clinical severity of diarrhoeal episodes. Scand J Infect Dis 1990;22:259-67.

2. Parashar UD, Holman RC, Bresee JS, et al. Epidemiology of diarrheal disease among children enrolled in four west coast health maintenance organizations. Pediatr Infect Dis 1999;17:611.

3. Griffith RI, Anderson GF, Powe NR, et al. Economic impact of immunization against rotavirus gastroenteritis. Arch Pediatr Adolesc Med 1995;149:407-14.

4. Takala AK, Koskenniemi E, Joensuu J, Makela M, Vesikari T. Economic evaluation of rotavirus vaccinations in Finland: Randomized, double-blind, placebo-controlled trial of tetravalent rhesus rotavirus vaccine. Clin Infect Dis 1998;27:272-82.

5. Ford-Jones EL, Wang E, Petric E, Corey P, Moineddin R, Fearon M, for the Greater Toronto Area/Peel region PRESI Study Group. Hospitalization for community-acquired, rotavirus-associated diarrhea. Arch Pediatr Adolesc Med 2000;154:578-85.

6. Ford-Jones EL, Wang E, Petric E, Corey P, Moineddin R, Fearon M, for the Greater Toronto Area/Peel region PRESI Study Group.
Rotavirus-associated diarrhea in outpatient settings and child care centers. Arch Pediatr Adolesc Med 2000;154:586-93.

7. Kapikian AZ, Evans AS, Kaslow RA, eds.Viral Infections of Humans. New York: Plenum Medical Book Company, 1997.

8. Waters V, Ford-Jones EL, Petric M, et al. Etiology of community acquired viral diarrhea. Pediatr Infect Dis 2000;19:843-8.

9. Canadian Institute for Health Information. Resource Intensity Weights. Summary of Methodology 1996/97. Ottawa: Canadian Institute for Health Information, 1996.

10. Joint Policy and Planning Committee. Methodology Used to Calculate 1998/99 Adjustment Factors Funding Model. Toronto: Joint Policy and Planning Committee of the Ontario Ministry of Health and the Ontario Hospital Association, 1998.

11. Ontario Ministry of Health. Ontario Schedule of Benefits. Toronto: Ontario Ministry of Health, 1997.

12. Ontario Ministry of Health. Ontario Drug Benefits Formulary. Toronto: Ontario Ministry of Health, 1997.

13. Statistics Canada. Economic indicators - Ontario (July 1998). Ottawa: Statistics Canada, 1998. 


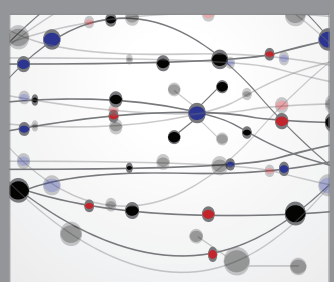

The Scientific World Journal
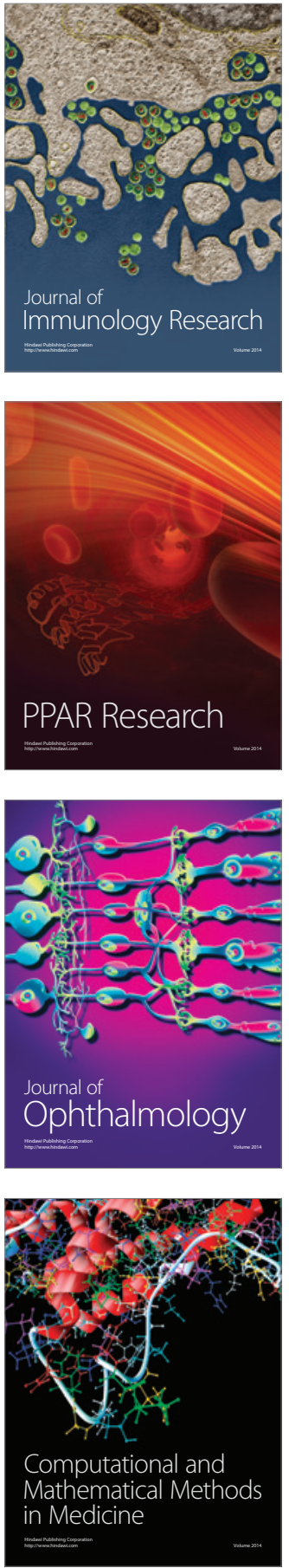

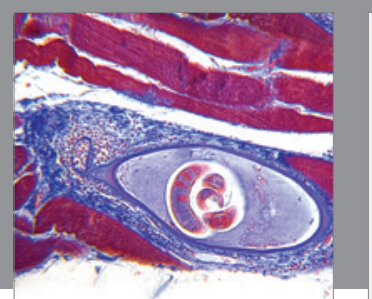

Gastroenterology Research and Practice

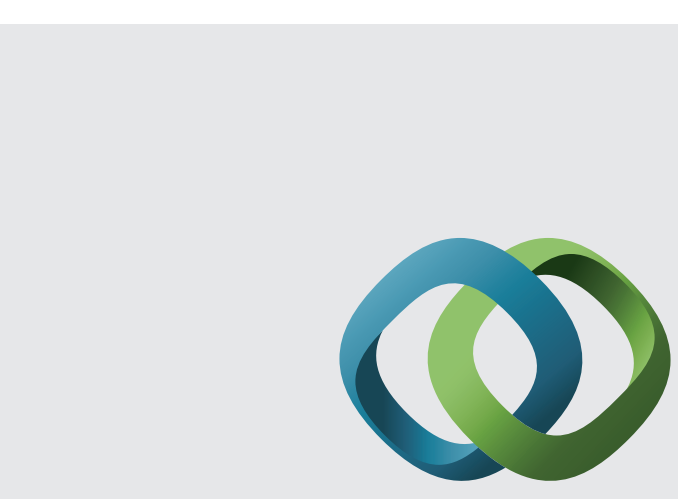

\section{Hindawi}

Submit your manuscripts at

http://www.hindawi.com
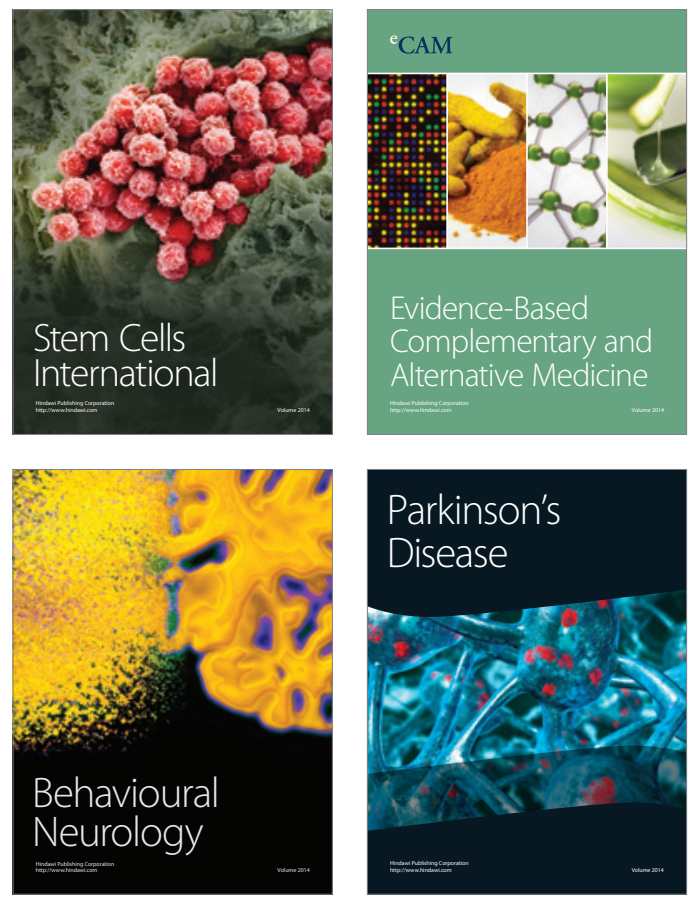
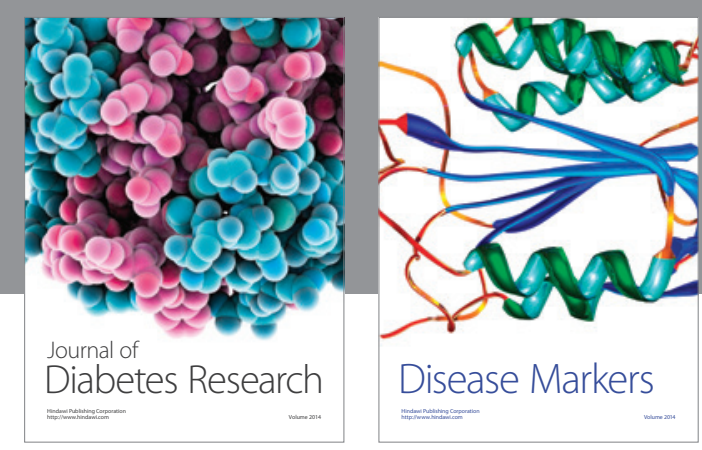

Disease Markers
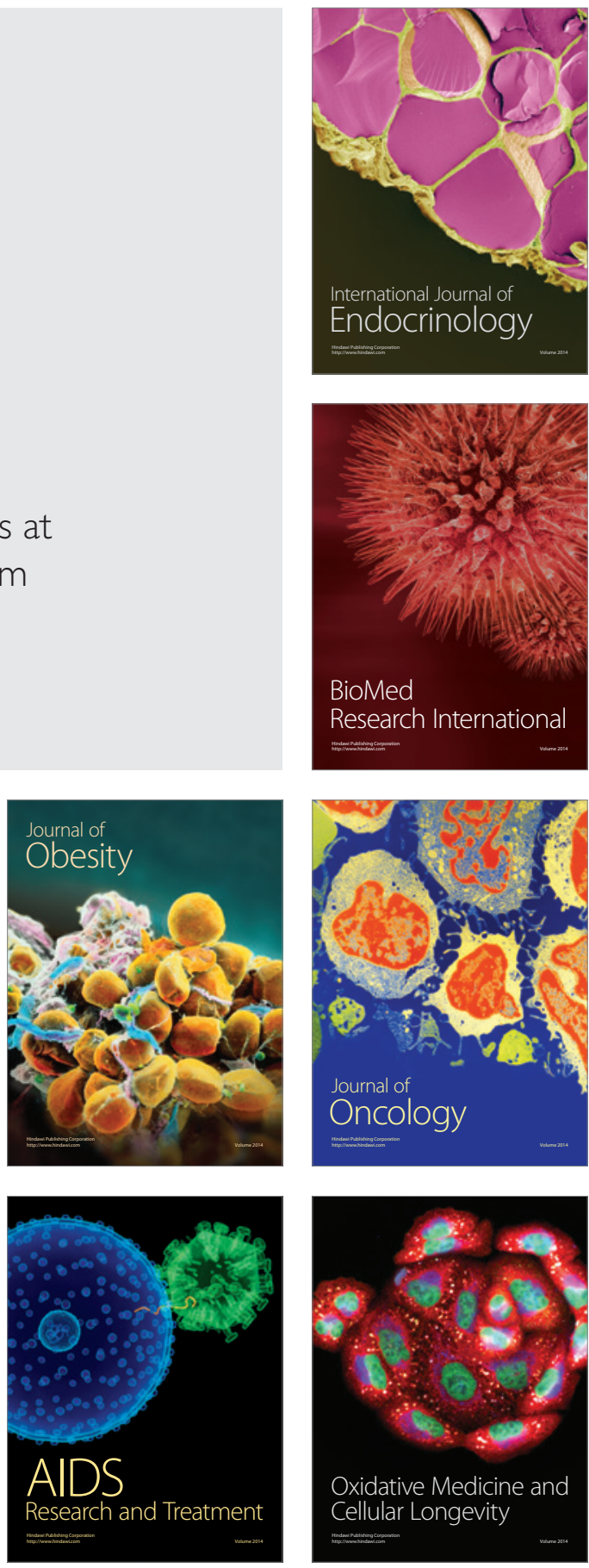